\title{
BBrescia

Beyond DASH: Examining the efficacy of the Mediterranean diet as a nutritionall strategy for

overweight or obese hypertensive children - A Systematic Review.

\section{Resvick $\mathbf{H}^{\mathbf{1}}$, Madill $\mathbf{J}^{\mathbf{1}}$, Hartman $\mathbf{B}^{\mathbf{1}}$}

1School of Food and Nutritional Sciences, Brescia University College, London Ontario

\section{Introduction}

The Mediterranean diet (MedDiet) is believed to be one of the healthiest dietary patterns and is associated with reduced cardiovascular risk and better weight management in adults. For these reasons, consideration for its use as a therapeutic option for primary pediatric hypertension (PPH) is warranted.

\section{Objectives}

1) to update research on the efficacy of the MedDiet for use in PPH.

2) to provide RDs with evidence-based therapeutic guidelines in practice.

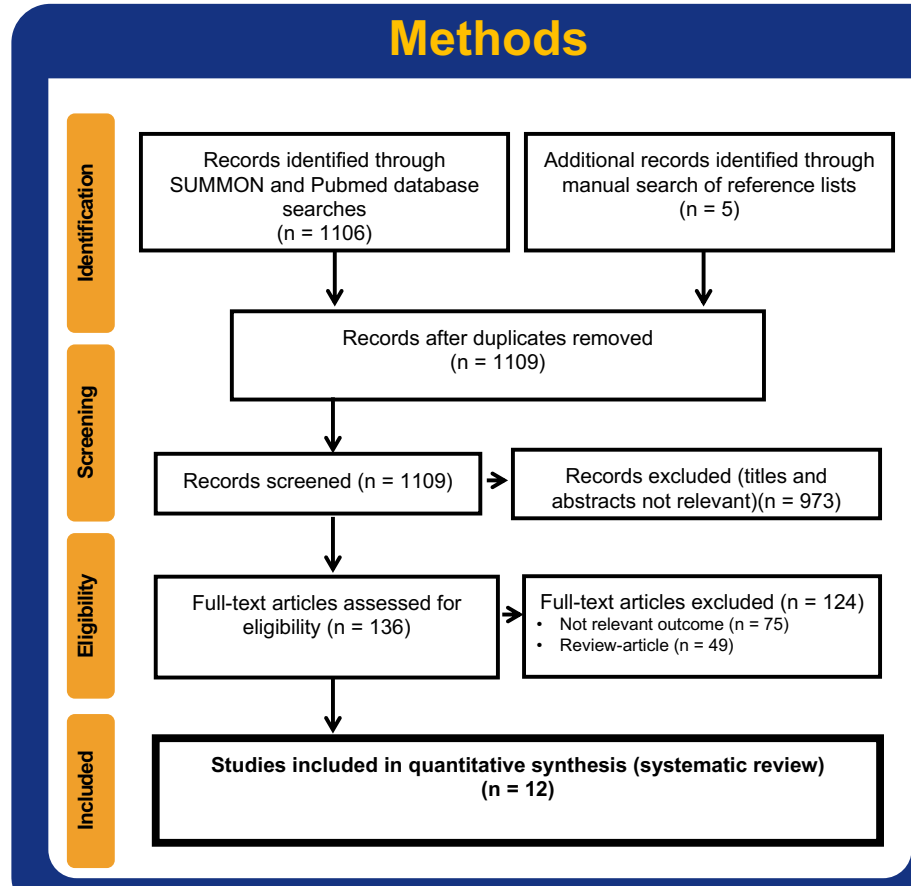

Results

- Greater adherence to the key components of the MedDiet including: fruit and vegetables, whole grains, legumes, nuts and seeds, fish, as well as olive oil result in decreased cardiometabolic risk and better weight management.

- Risk factors identified include: lower indices of arterial stiffness, lower prevalence of metabolic syndrome, lower BMI, decreased visceral adiposity and obesity, better lipid and blood glucose profile and healthier metabolic profile overall.

- Further, results also indicate that weight reduction and BMI play a role in blood pressure regulation in this population.

- A summary of the findings can be found in Table 1 .

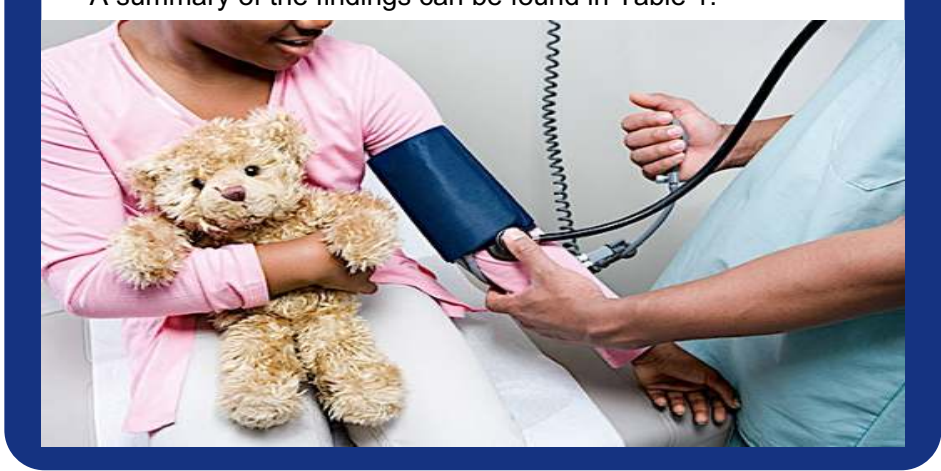

\section{Results}

Table 1: Summary of findings from journal articles

\begin{tabular}{|c|c|c|}
\hline Intervention & Journal & Findings \\
\hline \multirow{15}{*}{$\begin{array}{l}\text { Adherence to } \\
\text { MedDiet or } \\
\text { Elements of } \\
\text { MedDiet }\end{array}$} & $\begin{array}{l}\text { J Hum Hypertens. } \\
2009 ; 23(7)\end{array}$ & $\begin{array}{l}\text { - An Inverse association was found between adherence to MedDiet } \\
\text { and diastolic blood pressure. }\end{array}$ \\
\hline & & $\begin{array}{l}\text { - BMI and eating in front of the TV were positively associated with } \\
\text { BP. }\end{array}$ \\
\hline & $\begin{array}{l}\text { Eur J Pediatr. 2012; } \\
17(9)\end{array}$ & - Adherence to MedDiet was associated with augmentation index. \\
\hline & & $\begin{array}{l}\text { - Heart rate, height and BP were found to be significant factors in } \\
\text { arterial stiffness. }\end{array}$ \\
\hline & & $\begin{array}{l}\text { - Higher BMI and waist circumference resulted in peripheral and } \\
\text { central BP. }\end{array}$ \\
\hline & $\begin{array}{l}\text { Nutr Metab } \\
\text { Cardiovasc Dis. 2011; } \\
21(6)\end{array}$ & $\begin{array}{l}\text { - The proportion of adolescents with } 1 \text { or more risk factors for } \\
\text { metabolic syndrome increased with obesity. }\end{array}$ \\
\hline & & $\begin{array}{l}\text { - Higher adherence to the Med Diet was shown to be associated } \\
\text { with lower risk of metabolic syndrome. }\end{array}$ \\
\hline & Int J Cardiol. 2016;225 & $\begin{array}{l}\text { - Poor adherence to MedDiet and low physical activity among } \\
\text { children and adolescents resulted in a } 7 \text {-fold increase in metabolic } \\
\text { syndrome prevalence. }\end{array}$ \\
\hline & BioMed Res Int. 2017 & $\begin{array}{l}\text { - Adherence to MedDiet and physical fitness was associated with a } \\
\text { reduction in body weight, BMI, waist circumference, fat mass, waist } \\
\text { to hip ratio, and fat free mass. }\end{array}$ \\
\hline & $\begin{array}{l}J \text { Adolesc Health. } \\
2007 ; 40(2)\end{array}$ & $\begin{array}{l}\text { - Sedentary activities and BMI were found to be positively } \\
\text { associated with systolic blood pressure with every } 1 \text { hour increase in } \\
\text { sedentary behavior associated with } 0.2 \mathrm{mmHg} \text { increase in SBP. }\end{array}$ \\
\hline & & $\begin{array}{l}\text { - In } 12-15 \text { y.o. group for every } 1 \text { hour increase in watching TV/videos } \\
\text { increased systolic blood pressure by } 0.5 \mathrm{mmHg} \text {. }\end{array}$ \\
\hline & & $\begin{array}{l}\text { - Calcium and fibre after adjusting for energy were negatively } \\
\text { associated with systolic blood pressure }\end{array}$ \\
\hline & $\begin{array}{l}\text { Nutr Metab } \\
\text { Cardiovasc Dis. 2014; } \\
\text { 24(2) }\end{array}$ & $\begin{array}{l}\text {-High fMDS was inversely associated with being overweight or } \\
\text { obese, and fat mass. }\end{array}$ \\
\hline & & $\begin{array}{l}\text { - High fMDS at baseline had a protective effect against increases in } \\
\text { BMI, waist circumference, waist to height ratio and fat mass. }\end{array}$ \\
\hline & BMC Pediatr. 2014;14 & $\begin{array}{l}\text { - MedDiet group showed significant decreases in BMI, lean mass, fat } \\
\text { mass, blood glucose, cholesterol and triglycerides. }\end{array}$ \\
\hline \multirow{7}{*}{$\begin{array}{l}\text { No Association } \\
\text { with MedDiet }\end{array}$} & $\begin{array}{l}\text { Br J Nutr. } \\
2014 ; 112(10)\end{array}$ & $\begin{array}{l}\text { - MedDiet (healthy diet plan) was associated with lower pulse wave } \\
\text { volume }\end{array}$ \\
\hline & & $\begin{array}{l}\text { - No longitudinal relationship between MedDiet score and } \\
\text { cardiovascular risk was found }\end{array}$ \\
\hline & $\begin{array}{l}\text { Obes Res Clin Pract. } \\
2017 ; 11(2)\end{array}$ & $\begin{array}{l}\text { - Associations found between KIDMED score, BMI, waist } \\
\text { circumference and fat mass. }\end{array}$ \\
\hline & & $\begin{array}{l}\text { - Greater adherence to the MedDiet was associated with lower risk } \\
\text { of being overweight or obese. }\end{array}$ \\
\hline & & $\begin{array}{l}\text { - No association was found between MedDiet and lean muscle mass } \\
\text { or BP }\end{array}$ \\
\hline & Ecol Food Nutr. 2019 & $\begin{array}{l}\text { - Overweight adolescents were found to have elevated BP, } \\
\text { cholesterol, A1c, CRP, and lower HDL than normal weight peers }\end{array}$ \\
\hline & & $\begin{array}{l}\text { - No association was found between diet quality, obesity, and } \\
\text { cardiovascular risk factors }\end{array}$ \\
\hline $\begin{array}{l}\text { Sodium \& } \\
\text { MedDiet }\end{array}$ & $\begin{array}{l}\text { J Hypertens. } \\
2011 ; 29(6)\end{array}$ & $\begin{array}{l}\text { - Increased sodium intake was found in children with moderate to } \\
\text { high adherence to MedDiet with } 1 / 4 \text { of sodium coming from "hidden' } \\
\text { sources in bread, cereals and cheese }\end{array}$ \\
\hline
\end{tabular}

\section{Conclusions}

Research supporting the use of the Mediterranean diet as a therapeutic strategy for primary pediatric hypertension remains limited. There is convincing evidence for cardiometabolic risk reduction and weight management with the adherence to the key components of the Mediterranean diet.

\section{Significance to Dietetics}

An RD-supervised nutrition care plan that focuses on the Mediterranean diet may prove to be an effective tool for overweight or obese hypertensive pediatric patients. 